\title{
Faoro, Weber e a articulação das dimensões da realidade social na explicação do atraso brasileiro'
}

Hélio Afonso de Aguilar Filho²

\begin{abstract}
Resumo
O pensamento de Max Weber, no momento em que economistas e sociólogos procuram fazer convergir os seus trabalhos, apresenta-se como uma alternativa plausível para se pensar a inter-relação entre os vários domínios das Ciências Sociais. No Brasil, as ideias de Weber influenciaram várias gerações de pensadores, ocupando lugar de destaque na construção da história do pensamento social e econômico do país. Seguindo essa linha, este trabalho tem por objetivo analisar, em Os donos do poder, de Raymundo Faoro, um intérprete weberiano do Brasil, a articulação entre os distintos domínios do econômico, do social e do político. A hipótese fundamental é que, analisadas à luz de Weber, as formulações de Faoro subsumem toda a ação social em uma dimensão exclusiva, a da política, promovendo uma explicação monocausal do "atraso" e da dinâmica da realidade brasileira.
\end{abstract}

Palavras-chave: Max Weber. Raymundo Faoro. Imbricamento. Instituições. Atraso econômico.

\section{Introdução}

Há um interesse crescente por parte dos cientistas sociais em aproximar os resultados das pesquisas das suas diversas áreas, promovendo maior contato interdisciplinar entre os vários domínios do saber social. Esse interesse surgiu, por um lado, como uma reaçáo dos próprios economistas à crítica de que o objeto de estudo da economia teria esvaziado esse domínio das motivaçóes próprias das outras Ciências Sociais. Por outro lado, surgiu como uma reaçáo da sociologia e da ciência política à expansáo da teoria econômica da escolha racional sobre os seus domínios.

I Gostaria de agradecer aos professores Pedro Cesar Dutra Fonseca (UFRGS) e Hermógenes Saviani Filho (UFRGS), pelas contribuições e, como de praxe, ressaltar que os erros porventura existentes são de inteira responsabilidade do autor. Gostaria de agradecer também aos dois pareceristas anônimos da revista pelos comentários e sugestões.

2 Doutor em Economia pela Universidade Federal do Rio Grande do Sul (UFRGS), com ênfase em Economia do Desenvolvimento, Porto Alegre, Rio Grande do Sul, Brasil.Professor adjunto da UFRGS.E-mail: haaf73@yahoo.com.br. 
A abordagem da Nova Economia Institucional (NEI), com seu enfoque multidisciplinar, representa a tentativa por parte da economia de conciliar a especificidade e historicidade das instituiçóes das diversas sociedades com a abstraçáo e o enfoque generalizante característicos da teoria neoclássica. Da parte da sociologia, a contraofensiva tem se dado em amplas frentes. Uma das mais significativas vem das formulaçóes da Nova Sociologia Econômica. Em suas várias vertentes, os seus membros reconhecem, por exemplo, os avanços da NEI em relação à teoria neoclássica, mas criticam o que seria uma inserção artificial do social pelo econômico feita pelos adeptos da NEI. Nessa direçáo, há o resgate do conceito de embeddedness (imbricamento), na busca pelo reconhecimento da importância do ambiente e do contexto social em que os agentes estáo inseridos.

Outra frente sociológica intenta um retorno à sociologia clássica como solução para se pensar a articulação entre os vários níveis da realidade social. Esse é o caso de Swedberg (2005) e Boettke e Storr (2002), que criticam a forma como o econômico e o social se vinculam tanto nos trabalhos da Nova Sociologia Econômica quanto nos da NEI, os primeiros por sobressocializarem o comportamento humano; enquanto os segundos, por subsocializarem. Em contrapartida, esses autores apontam a teoria weberiana como a mais adequada em reconhecer os níveis múltiplos do embeddedness. O interesse por Weber se manifesta também porque este confere uma atençáo especial ao capitalismo como sistema econômico-social distinto. Suas categorias de "capitalismo racional" e "político" foram, até o momento, pouco exploradas, abrindo amplas possibilidades explicativas para se entender a história dos países em desenvolvimento.

No Brasil, a produção intelectual de Weber, ao lado da de Marx, foi a que mais fortemente influenciou os estudos dos problemas do país. Seu legado envolve a adiçáo de vários fatores não econômicos na compreensão da realidade brasileira. Para o caso, cita-se Raymundo Faoro, que usa as ideias de Weber como um contraponto à tópica marxista da determinaçáo da superestrutura política e ideológica pela infraestrutura econômica. Faoro faz uso também das noçóes de patrimonialismo, capitalismo político e estamento, próprias da sociologia de Weber, para explicar o "atraso" econômico, político e social brasileiro comparativamente ao progresso americano.

O objetivo deste trabalho, seguindo a perspectiva aberta pela sociologia econômica weberiana, é analisar em Os donos do poder, de Raymundo Faoro, a 
articulação entre os distintos domínios do econômico, do social e do político. A hipótese fundamental é que, analisadas à luz de Weber, as formulaçóes de Faoro (1997) subsumem toda a ação social a uma dimensão exclusiva, a saber, a política, promovendo uma explicaçáo monocausal do "atraso" e da dinâmica da realidade brasileira.

Os estudos mais recentes sobre desenvolvimento econômico, ao confirmarem a importância de fatores não econômicos na explicação do desempenho diferenciado entre as naçóes no tempo, justificam em grande medida este artigo. Ademais, a atualidade de Weber para se pensar as várias formas do capitalismo e o imbricamento entre os domínios das Ciências Sociais abre possibilidades também para se pesquisar a obra dos intérpretes weberianos do Brasil, bem como suas explicaçóes para o atraso brasileiro.

Este trabalho, além desta introduçáo, divide-se como segue. A segunda seção apresenta os conceitos da sociologia econômica de Weber, contrapondo-os às outras tentativas de articular os vários domínios da realidade social. A terceira apresenta a interpretação de Faoro (1997) e a forma como este articula os conceitos weberianos na explicaçáo do descompasso brasileiro ao longo da história. Por fim, seguem as conclusóes deste artigo.

\section{0 método compreensivo e a sociologia de Max Weber}

Nas últimas décadas, em resposta às críticas de que a teoria neoclássica teria esvaziado a análise econômica das motivaçóes estudadas pela sociologia e pela política, tem havido esforços para aproximar os resultados das pesquisas econômicas dos resultados das demais Ciências Sociais. Essa aproximaçáo tem sido facilitada pelo entendimento de que a divisão das Ciências Sociais diz respeito mais a diferenças de abordagens do que de disciplinas e, em última análise, de que essas abordagens podem ser conciliadas pelo conceito de instituiçóes (DEQUECH, 2011). Nesse contexto, as ideias de Weber (1991, 1994, 2001), evidenciadas neste trabalho, têm relevância, primeiro por representarem uma solução para a separação entre conhecimento histórico e nomotético e, segundo, porque seu sólido alicerce conceitual tem sido alternativa às tentativas de tratar da questáo dos múltiplos níveis de embeddedness. ${ }^{3}$

3 Boettke e Storr (2002) criticam a forma como o econômico e o social se vinculam tanto nos trabalhos da Nova Sociologia Econômica quanto nos da NEI. No caso da Nova Sociologia Econômica, nem mesmo as 


\section{I Conciliando o método histórico e o método abstrato dedutivo}

A disputa que influenciou a separação da economia das demais Ciências Sociais ocorreu na Alemanha do século XIX, opondo monistas a pluralistas metodológicos. $\mathrm{Na}$ economia, esse embate ficou conhecido como "Batalha dos Métodos", 4 colocando em campos opostos aqueles que apoiavam a Escola Marginalista, liderada por Carl Menger, contra a chamada Escola Histórica Alemá, liderada por Gustav Schmoller. As principais controvérsias deram-se, principalmente, em torno da questáo da natureza do objeto econômico e da melhor forma de abordá-lo.

A contribuiçáo de Weber para a resoluçáo da disputa metodológica na Alemanha deu-se ao operar a fusão e a consequente unificação das Ciências Culturais e Sociais (RINGER, 2004). Primeiro, por reconhecer que náo existe privilégio ou superioridade do método generalizante em relação ao método individualizante; tanto as Ciências Naturais quanto Culturais fazem uso de ambos os métodos na tentativa de dar uma explicação causal aos fenômenos. Qualquer que seja o método, cada uma faz uma seleção na infinita diversidade da realidade empírica:

O método generalizante despoja o real de todos os aspectos contingentes e singulares, reduzindo as diferenças qualitativas a quantidades que podem ser medidas com precisão e podem formar uma proposição geral de caráter legal. O método individualizante omite os elementos genéricos, a fim de dirigir sua atenção apenas aos caracteres qualitativos e singulares dos fenômenos. (FREUND, 2006, p. 34).

A segunda contribuição de Weber deu-se na medida em que conectou as noçóes de explicação e interpretação através da sua "análise causal singular". Por "singular" o autor entende os eventos que podem ser explicados, em sentido lógico, e, especificamente, identificados e localizados tanto no espaço quanto no tempo. Pensar as realidades históricas, culturais e sociais é pensá-las

indicações de Mark Granovetter e sua crítica à subsocialização e sobressocialização, feitas, respectivamente, aos neoclássicos e aos novos institucionalistas, foram suficientemente fortes em reconhecer os niveis múltiplos do embeddedness.

4 De acordo com Swedberg (1990), estaria ocorrendo mais recentemente uma "Nova Batalha dos Métodos". Enquanto a primeira teria dado os passos iniciais para marcar a separação da teoria econômica em relação à história e à sociologia, a segunda estaria contribuindo para levar ao fim as tradicionais formas de análise das Ciências Sociais. 
como algo infinitamente complexo, permeado de relaçóes causais entre dados específicos. No esquema de Weber, esses elementos devem ser explicados através de comparaçôes probabilísticas e contrafactuais, isto é, por atribuição hipotética de racionalidade, sendo em seguida comparados com os comportamentos previstos com os cursos de açáo tomados na realidade. Dessa forma, é possível, conforme assinala Ringer (2004), ajustar ou suplementar as concepçóes de açáo racional a fim de explicar as divergências entre essas formas de raciocínio e a ação real que se deseja entender, além dos motivos irracionais e outros fatores intervenientes.

Uma demonstração da íntima conexáo entre interpretação e explicaçáo no pensamento weberiano advém do seu conceito de tipo ideal. Na visão de Weber, ${ }^{5}$ esses tipos ideais devem ser concebidos como "utopias" com valor heurístico, ao permitir as comparaçóes contrafactuais implícitas na elaboraçáo de interpretaçóes ou explicaçóes adequadas. Nas palavras do próprio Weber (2001, p. 402):

O método científico que consiste na construção de tipos investiga e expõe todas as conexões de sentido irracionais e afetivas sentimentalmente condicionadas do comportamento que têm influência sobre a ação como 'desvios' de um desenvolvimento desta mesma ação que foi construída como sendo puramente racional em relação aos fins. ${ }^{6}$

A solução de Weber para a divisáo entre conhecimento histórico e nomotético teve especial destaque no curso das Ciências Sociais. De acordo com os pressupostos metodológicos com os quais o autor assenta seu conhecimento, sendo a realidade diversa e infinita, só os aspectos que recebem significaçáo geral para a cultura merecem ser conhecidos, constituindo-se em objeto de explicaçáo causal. A primazia de uma perspectiva específica na explicaçáo de determinado conjunto de fenômenos não é arbitrária; baseia-se nas vantagens

5 Um exemplo do que foi exposto são as construções da teoria econômica. Concebendo a impossibilidade de apropriação do real, os economistas, a partir de Menger, dirigiram seus estudos no sentido de decompor os fenômenos complexos em constituintes e relações mais elementares, passiveis de serem representadas por tipos e leis rígidas e invariáveis. Nesse sentido, a economia postulará individuos bem-informados, racionais e puramente econômicos. A ideia aqui, segundo Weber (200I), é a de que essa construção é um tipo ideal, constituindo-se em uma elaboração mental heuristicamente útil para contrapor-se à realidade entendendo os seus desvios.

6 Para ser mais preciso, o compreensivel é, pois, a sua referência "[...] à ação humana, seja como 'meio', seja como 'fim' imaginado pelo agente ou pelos agentes que orientaram a sua ação" (WEBER, 200I, p. 402). 
da divisáo do trabalho acadêmico ${ }^{7}$ e na capacidade dessa perspectiva em oferecer conhecimento de relaçóes e imputar causas a determinados acontecimentos históricos concretos.

Apesar, entretanto, da multiplicidade de pontos de vistas e abordagens admitidas pela realidade, tornou-se comum na história das ciências, segundo Weber (2001), a tentativa de produzir, além de conhecimentos específicos, "conhecimentos do mundo", ou explicaçóes monocausais dos fenômenos. O caso das Ciências da Cultura da sua época ilustra bem esse fato, quando, a partir do ponto de vista materialista, tentava-se explicar a totalidade dos fenômenos da vida social "como produto ou funçáo de determinadas constelaçóes de interesses materiais" (WEBER, 2001, p. 121). O autor se coloca frontalmente contra esse tipo de reducionismo nas Ciências da Cultura. A forma como ele lida com essa questáo tem relaçáo direta com o tema tratado a seguir, o da inter-relaçáo entre os vários campos do saber social, ou dos distintos níveis de embeddedness.

\subsection{A sociologia econômica de Weber}

Para Swedberg (2005) e Boettke e Storr (2002), a perspectiva de Weber é a mais adequada para se compreender conceitualmente a inter-relaçáo entre o domínio do econômico, do político e do social. O que confere superioridade ao embeddedness weberiano é a metodologia do autor, que sustenta um individualismo sofisticado. O ponto de partida de Weber $(1991,2001)$ não são as entidades coletivas, grupos ou instituiçóes, mas o indivíduo e sua atribuiçáo proposital de sentido à açáo. A particularidade do seu individualismo metodológico reside no fato de que nele os indivíduos são influenciados e afetados pelo contexto significativo no qual estáo situados, ao mesmo tempo que sáo também produtores e criadores desse contexto. Náo há, portanto, espaço para agentes sociais desincorporados nem estruturas sociais e relaçóes dissociadas das redes de entendimentos que lhes dáo forma.

$\mathrm{Na}$ abordagem weberiana, a distinçáo entre as dimensóes social, econômica e política ocorre somente a partir do contexto e do sentido subjetivo que os indivíduos conferem à açáo. Tendo em vista essa condiçáo, cabe ao

7 Até mesmo porque Max Weber faz questão de salientar que a autonomia relativa dessas esferas e a criação de inúmeras áreas do conhecimento - essencialmente, as efetuadas nas Ciências Sociais - advêm da tendência à racionalização, à secularização e ao individualismo, traços dominantes da civilização ocidental e da modernidade. 
pesquisador das Ciências da Cultura relacionar o pensamento formal às manifestaçóes empíricas, a fim de classificar o domínio ao qual a ação pertence. $\mathrm{O}$ sociólogo, por exemplo, procura compreender o significado ou sentido próprio quando esse sentido se relaciona com o comportamento de outras pessoas. $\mathrm{Na}$ busca por desvendar os nexos causais dessas açóes, sáo considerados tanto os interesses ideais quanto os interesses materiais dos agentes. O economista, por sua vez, trata da relaçáo humana que tem por base uma necessidade ou um complexo de necessidades que exigem satisfação, enquanto os meios e os atos capazes de proporcionar essa satisfaçáo estáo limitados quer pela raridade, quer por uma penúria, quer por uma indigência dos recursos de aquisiçáo (WEBER, 1991, 2001). As situaçóes analisadas pela economia devem envolver agentes movidos principalmente pelos interesses materiais, tendo a utilidade como objetivo, mas esta não deve levar em conta o comportamento dos outros (ação econômica). ${ }^{8}$

No caso da sociologia econômica, ${ }^{9}$ seu estudo abrange uma área muito maior do que a da teoria econômica; ambas, contudo, têm um tema em comum, a saber, a açáo econômica é social e racional e tem objetivos exclusivamente econômicos. Além disso, a teoria econômica estuda a ação racional que tem objetivos exclusivamente econômicos e que náo é social. $\mathrm{O}$ caso mais importante de açáo econômica irracional é o comportamento tradicional. $\mathrm{O}$ termo usado por Weber (2001) para designar a açáo econômica que náo tem objetivos exclusivamente econômicos, mas sofre motivaçáo econômica, é "fenômeno economicamente condicionado", podendo ser citados, nesse caso, os fenômenos da vida cotidiana, da política, quando recebem o condicionamento de motivos econômicos - estes se contrapóem aos "fenômenos econômicos" propriamente ditos e aos "fenômenos economicamente relevantes". Os "fenômenos econômicos" abrangem aqueles em sentido estrito, tal como eventos econômicos e instituiçóes econômicas, por exemplo, acontecimentos da vida

8 De acordo com Swedberg (2005), existem três diferenças básicas, as quais, consideradas em conjunto, podem melhor informar sobre a relação entre teoria econômica e sociologia dentro da perspectiva weberiana: I) a teoria econômica, ao contrário da sociologia, só leva em conta o comportamento racional; 2) a teoria econômica, ao contrário da sociologia, só leva em conta o comportamento com objetivos puramente econômicos; e 3) a sociologia considera exclusivamente a ação social, ou seja, a ação que é voltada para o comportamento dos outros.

9 Ainda de acordo com Swedberg (2005), a sociologia econômica weberiana ou economia política enfocaria a ação social econômica - isto é, a ação movida, principalmente, pelos interesses materiais, que é voltada para a utilidade e leva outros agentes em conta. A ação social e a ação social econômica também podem ser movidas pelo hábito (ou tradição) e pelas emoções combinadas com os interesses. 
bancária e da bolsa, que interessam, essencialmente, desse ponto de vista. Normalmente esses fenômenos atuam onde a satisfaçáo de uma necessidade, por mais imaterial que seja, envolve a utilizaçáo de meios limitados. Os "fenômenos economicamente relevantes" descrevem os eventos e as instituiçóes que náo sáo econômicos no sentido estrito, mas que têm consequências econômicas. Podem ser citados, nesse caso, os fenômenos da vida religiosa e cultural, quando dáo forma a motivos econômicos.

Na próxima seção, aborda-se a forma como as categorias weberianas ganham sentido na explicaçáo do "atraso" brasileiro por Raymundo Faoro. A ênfase é para as noçóes de fenômenos economicamente relevantes e economicamente condicionados de Weber, que serão usados para analisar a articulação dos domínios do político, do social e do econômico em Faoro.

\section{Faoro e a articulação do econômico, do político e do social na explicação do atraso}

Raymundo Faoro, ${ }^{10}$ em Os donos do poder, faz uso de uma série de conceitos próprios da sociologia weberiana, como patrimonialismo, estamento e capitalismo político para entender o Brasil. $\mathrm{O}$ autor estuda seis séculos de história, partindo da origem do Estado português até as transformaçóes políticas ocorridos na década de 1930, durante o governo de Getúlio Vargas. Com isso, e em oposiçáa às teses mais antropológicas ${ }^{11} \mathrm{da}$ época, o autor passa a identificar uma estrutura de dominaçáo que, transposta para o Brasil, foi a responsável pelos problemas do Estado e da sociedade brasileira.

Desde o lançamento do seu livro, Raymundo Faoro se constitui em um dos grandes pensadores da realidade brasileira e $O s$ donos do poder em um referencial apropriado - apesar de pontos questionáveis à luz de pesquisas historiográficas recentes (CARVALHO, 1980; FRANCO, 1976) - e muito atual para a compreensáo dos problemas que hoje afligem a sociedade brasileira.

As subseçóes a seguir analisam alguns dos conceitos empregados por Faoro (1997), com ênfase na articulação dos domínios do político, do social e do econômico na sua explicaçáo do atraso do Brasil.

10 Vale ressaltar que, entre os intérpretes weberianos do Brasil, um aspecto a diferenciar Raymundo Faoro é, segundo Souza (1999), a sua abordagem mais "institucionalista", sem, contudo, descuidar-se dos aspectos socioculturais inerentes ao comportamento prático.

II Principalmente a tese de Gilberto Freyre em Casa-Grande E senzala. 


\section{I Faoro, Weber e o determinismo econômico}

A preocupaçáo fundamental de Faoro em Os donos do poder foi apresentar uma explicação para o descompasso histórico brasileiro que o distanciasse ao mesmo tempo do marxismo ortodoxo. A razão disso está no fato de o autor interpretar o marxismo como um reducionismo, na medida em que esse referencial apresenta o domínio do econômico como o nexo causal necessário ao entendimento da realidade social. A sua ruptura definitiva com esse modo de ver o mundo vem com a oposição a duas noçóes centrais do materialismo histórico: primeiro, a ideia de que a infraestrutura econômica determina em última instância a superestrutura política, jurídica e ideológica e, segundo, quanto ao papel da luta de classes e sua centralidade na explicaçáo da história da sociedade humana.

Em oposição ao marxismo ortodoxo, Faoro (1997) procura na sociologia de Weber conceitos que visam atenuar e mesmo diminuir a importância explicativa dos fatores econômicos. Nesse sentido, quando a dimensáo econômica aparece na sua obra, é com a marca do seu enraizamento no político. Uma amostra desse procedimento é o tratamento dispensado a categorias tais como mercado, moeda, burguesia e capitalismo. No caso específico do mercado, Faoro (1997, p. 47) aponta que, desde o seu nascimento e difusão no mundo ibérico, as convençóes, os estilos de vida incidem sobre ele, "impedindo-o de expandir sua plena virtualidade de negar relaçóes pessoais". A moeda também aparece como instrumento privado, apropriada pelo soberano e, posteriormente, pelos grupos de status. No Brasil, conforme corrobora Galvan (2001), ela foi muito mais instrumento do Rei que meio de trocas, pois as trocas se efetuavam principalmente em funçáo da apropriaçáo pelo Rei e pelos grupos de poder das riquezas existentes.

A burguesia portuguesa, que poderia representar um contrapeso à particularizaçáo do mercado e dos seus instrumentos, em vez de se fazer portadora de uma nova ordem, mais universalista e de "acesso aberto", continuou presa aos vínculos tradicionais. Nas palavras do próprio Faoro (1997, p. 60):

Acomodou-se ao Estado maior que a cercava e triturava impondo-lhe o estilo de vida. Esta marca social, esta estratificação impediu-lhe a emancipação, lançando sobre ela descrédito ao trabalho manual em favor de valores que consagravam a ociosidade letrada. 
A justificativa do autor para esses fatos, mais uma vez, está no papel maior da política na explicação histórica. Seguindo a tradição weberiana, Faoro (1997) dá o nome de patrimonialismo ${ }^{12}$ às relaçóes de dominaçáo existentes em Portugal. Nesse país, os servidores do Estado estáo presos “[...] numa rede patriarcal, na qual eles representam a extensáo da casa do soberano" (FAORO, 1997, p. 20). Tivesse Portugal passado pelo feudalismo, a história poderia ter seguido outro caminho. A importância do feudalismo está em permitir o estabelecimento de vínculos entre soberanos e súditos por meio de relaçóes contratuais; estas estabelecem limites ao exercício do poder, assegurando aos súditos o direito de resistência quando ultrapassadas as fronteiras de comando. Por isso, para Faoro (1997, p. 18), há uma

[...] insuperável incompatibilidade do sistema feudal com a apropriação, pelo príncipe, dos recursos militares e fiscais - fatores que levaram a intensificar e racionalizar o Estado, capaz, com o suporte econômico, de se emancipar, como realidade eminente, das forças descentralizadas que o dispersam, dividem e anulam.

A passagem pelo feudalismo sinaliza, portanto, a existência de relaçóes contratuais, e estas são a expressáo máxima da racionalidade requerida pelo capitalismo moderno. $\mathrm{O}$ formato de economia que nasce das relaçóes patrimoniais, em contrapartida, é mais condizente com o mercantilismo e, diga-se, inapropriado para o capitalismo moderno. Nas palavras do próprio Faoro (1997, p. 18), dominante o patrimonialismo,

[...] com sua ordem burocrática e com o Estado dirigindo a sociedade, impede-se a autonomia da empresa, anulando a esfera das liberdades públicas, fundadas sobre as liberdades econômicas, a saber, livre contrato, livre concorrência e livre profissão, opostas, todas elas, aos monopólios e concessões régias.

Do exposto, tem-se que a aproximaçáo de Faoro (1997) com relaçáo a Weber está na crença de que o capitalismo moderno implica o desenvolvimento

12 O patrimonialismo, para Weber (199I), é um tipo de dominação tradicional. A dominação tradicional ocorre quando sua legitimidade repousa na crença na santidade de ordens e poderes senhoriais tradicionais. Determina-se o senhor em virtude de regras tradicionais. O dominante não é um "superior", mas senhor pessoal; seu quadro administrativo não se compõe primariamente de "funcionários", mas de servidores pessoais, e os dominados não são "membros" da associação, mas companheiros tradicionais ou súditos. No caso do feudalismo, este representa um tipo de dominação que possui tanto elementos tipicamente patrimoniais - como o culto à fidelidade pessoal ao governante - quanto caracteristicas tipicamente extrapatrimoniais - como a complexa e minuciosa estipulação contratual de direitos e deveres entre governantes e quadro administrativo. 
de uma racionalidade ou sistematicidade na busca dos lucros, culminando num método de empresa. A ruptura, segundo Lessa (2009), está no fato de Faoro (1997) ter negado a associaçáo entre espírito capitalista e ética protestante, ao considerar que somente países que vivenciaram e superaram o feudalismo teriam adotado de forma plena o capitalismo, nele integrando sociedade e Estado. Essa noção é confirmada pelo próprio Faoro (1997), ao assumir que sua proximidade com Weber é expressáo de um afastamento com relaçáo a Marx. Isso pode ser constatado logo no prefácio à segunda edição de Os donos do poder, em que o autor adverte náo seguir a linha de pensamento de Max Weber, embora seus conceitos tenham um parentesco próximo. Vale ressaltar, entretanto, que Faoro (1997) estava equivocado quanto à posição de Max Weber a respeito do surgimento do capitalismo moderno, pois para Weber (1994) há uma multiplicidade de causas influenciando o surgimento do capitalismo, podendo ser estas de cunho político, religioso e/ou econômico. $\mathrm{Na}$ "Ética Protestante...", o autor explora apenas uma dessas causas, a da importância dos fatores ideais por meio da influência do protestantismo ascético. ${ }^{13} \mathrm{E}$ isso o que diz o próprio Weber (1994, p. 132) ao final do livro, quando suscita novas pesquisas históricas sobre o nascimento do capitalismo no Ocidente:

Aqui apenas se tratou do fato e da direção de sua influência em apenas um, se bem que importante ponto de seus motivos. Seria, todavia, necessário investigar mais adiante, a maneira pela qual a ascese protestante foi por sua vez influenciada em seu desenvolvimento e caráter pela totalidade das condições sociais, especialmente pelas econômicas.

Outro conceito weberiano usado por Faoro (1997) para marcar o distanciamento com relação à análise reducionista feita pelo marxismo ortodoxo foi o de estamento. Este, de acordo com Weber (1991), é uma camada social e náo econômica. Sociedades onde persistem os estamentos sáo classificadas como convencionais, sendo reguladas por normas de modos de vida opostas à formaçáo do livre mercado. ${ }^{14}$ Faoro (1997) segue fielmente a definição de Weber,

13 Ver Swedberg (2005, p. 37-38), em sua interpretação de Weber: "o capitalismo racional ou o capitalismo ocidental pressupõe uma sociedade em que o tradicionalismo perdeu sua influência sobre as pessoas e onde o sistema predominante de valores é favorável à obtenção de lucros. Pressupõe também Estado político com estatuto jurídico previsivel e universal, além de tecnologia racional e trabalho formalmente liure".

14 "Apesar de os estamentos serem característicos de sociedades onde não impera o mercado, podem persistir ainda que residualmente no capitalismo. O fechamento da comunidade leva à apropriação de oportunidades econômicas que acabam virando monopólios de atividades lucrativas e cargos públicos" (FAORO, 
usando o termo para identificar, no Brasil, a autonomia de uma camada de poder não diluída numa infraestrutura esquemática, que daria conteúdo econômico a fatores de outra índole. A ruptura de Faoro $(1997)^{15}$ para com Weber ocorre quando ele caracteriza a situaçáo de países que foram dominados pelo comércio mercantilista e que promoveram o surgimento de Estados nacionais modernos, sem, contudo, criar uma burocracia racional legal. Impera, nesse caso, um tipo de dominaçáo tradicional, o patrimonialismo estamental. Em contraposição, segundo Campante (2003), Max Weber teria usado o conceito para entender originalmente a atuação de grupos de status que têm o seu centro de poder baseado na dominaçáo territorial, atuando em uma economia não ou pouco monetizada.

No que diz respeito ao Brasil, para Faoro (1997) é justamente a estrutura patrimonial trazida pelos portugueses que teria moldado a colonizaçáo e o posterior desenvolvimento da sociedade. A própria descoberta seria "[...] negócio do Rei, integrada à estrutura patrimonial, visado nas armas e com fins ao comércio" (FAORO, 1997, p. 108). Ademais, a especificidade do caso brasileiro está na compatibilidade do patrimonialismo com o capitalismo moderno. A modalidade de capitalismo existente aqui é a do politicamente orientado, gerido, segundo Faoro (1997), na esfera política pela comunidade que comanda, conduz e supervisiona os negócios públicos.

Uma questáo adicional sobre a importância da política no modelo explicativo de Faoro (1997), que vale salientar, é o fato de a estrutura patrimonial estamental trazer consequências de longa duraçáo para a dinâmica da mudança institucional na sociedade brasileira. Isso porque esta passa a ocorrer a partir do estamento, que forma o "elo vinculador com o mundo externo e que pressiona pelo domínio de seus padróes” (FAORO, 1997, p. 745), incorporando e simultaneamente controlando as novas forças sociais.

1997. p. 46). Isso significa que as convenções e os estilos de vida incidem sobre o mercado, restringindo-o. Por sua própria natureza, os estamentos se fortalecem com a estabilidade e se enfraquecem com as mudanças. Dai representarem um freio conservador preocupado em assegurar seu poder. Os diversos grupos se orientam dentro dos limites definidos, que são estabelecidos de cima para baixo.

15 Para Faoro (1997), no primeiro estágio do domínio patrimonial, os grupos que detinham o poder se apropriaram das oportunidades econômicas, das concessões, dos cargos, através da confusão entre o setor público e o privado. Com o desenvolvimento da estrutura política característica da formação dos Estados Nacionais, apareceram as competências fixas e a divisão de poderes, ocasionando, assim, a separação entre o setor fiscal e o pessoal. Tem-se, então, a constituição do estamento burocrático. 


\subsection{O embeddedness weberiano e a interpretação de Faoro para o atraso do Brasil}

A forma como Faoro (1997) articula as distintas dimensóes da realidade social é bem característica, mas guarda distância também com relação à explicação de Weber. Primeiro, porque este último se vale, diga-se mais uma vez, de vários elementos para explicar o capitalismo; segundo, porque o embeddedness weberiano (açáo econômica social) só pode ser pensado a partir do método compreensivo. Neste fica claro que a análise da açáo social deve começar necessariamente pelo indivíduo e sua atribuiçáo proposital de sentido à açáo. Assim, a classificaçáo de uma açáo como social, econômica ou política deve ocorrer a partir do entendimento e do sentido subjetivo atribuído pelos próprios indivíduos envolvidos.

Nota-se que, mesmo tendo o indivíduo como ponto de partida para o entendimento dos fenômenos sociais, Weber consegue resguardar as estruturas e as instituiçóes na compreensáo dos fenômenos sociais. Diferentemente de outras abordagens que analisam o social e as instituiçóes tomando o hábito, as convençôes como ponto de partida da pesquisa econômica e social, Weber concebe essas regularidades, ou as açóes sociais repetidas, como tendo por base o comportamento individual e as expectativas guardadas com relaçáo ao comportamento do outro. Nesse caso, a ocorrência dessas regularidades está, por sua vez, relacionada à probabilidade de que certas açóes entre pessoas ocorram em média ou por exercício de fato.

$\mathrm{Na}$ interpretação de Faoro (1997) sobre o Brasil, embora use conceitos weberianos, o autor se afasta da metodologia de Weber. Sua ênfase recai, principalmente, em noçóes como patrimonialismo, estamento, estratificação e capitalismo politicamente orientado. Mesmo tendo origem na sociologia de Weber, tais categorias, como sustentam Gerth e Mills (1974, p. 75), náo se acomodam bem com o método compreensivo, pois se constituem em um tipo de explicaçáo que tenta "justificar a motivaçáo dos sistemas de ação pelas suas funçóes ou como estruturas funcionais e não pelas intençóes subjetivas dos indivíduos que as praticam".

Como visto, Weber (2001) usa alguns conceitos para marcar de forma mais precisa o domínio do econômico. Relembrando, postula a existência de fenômenos estritamente econômicos e de fenômenos náo econômicos. 
Estes últimos podem interessar à economia tanto pelos seus efeitos quanto por serem causados por fatores econômicos. Para melhor entender a ligação desses conceitos com o embeddedness de Weber, pode-se pensar, assim como sugerido por Boettke e Storr (2002), em três círculos de tamanhos potenciais diferentes, representando, respectivamente, a sociedade, o político e a economia. Arranjando esses círculos dentro da configuraçáo do argumento do embeddedness da Nova Sociologia Econômica, por exemplo, ter-se-ia que conceber o círculo que representa a sociedade como o maior, o do político como o segundo maior e o da economia como o menor, localizado dentro dos dois maiores. Isso porque as açôes que no modelo weberiano seriam tratadas como "economicamente relevantes" tomam a primazia sobre as outras esferas. A vida econômica, nessa configuraçáo, é situada dentro das redes de "relaçōes sociais", ou seja, nesse caso, é sempre a sociedade que as influencia e confina o comportamento econômico.

Como advertem Boettke e Storr (2002), ao estabelecer a configuraçáo mencionada, náo há nada de logicamente inconsistente em imaginar o inteiramente oposto, ou seja, poder-se-ia colocar a sociedade dentro da economia. Esse é precisamente o desenho que muitos marxistas imaginam quando concebem a influência, em última instância, da infraestrutura sobre a superestrutura (sociedade dentro da economia). ${ }^{16}$ Essa imagem, ainda seguindo os autores, pode ser estendida de modo a englobar as explicaçóes dos novos institucionalistas. Aqueles incentivos econômicos, tais como a instituiçáo de direitos de propriedade, os contratos e mesmo as normas e os valores tratados pela NEI, estariam caracterizados dentro do que Weber chamou "fenômenos economicamente condicionados". ${ }^{17}$

Mas e Faoro (1997), como se situa dentro dessa conceituaçáo? O autor também incorre no problema de subsumir a açáo social em uma única categoria, promovendo uma explicaçáo da realidade brasileira a partir de um único nível do embeddedness? $\mathrm{O}$ argumento principal deste trabalho é que sim, Faoro (1997) imbrica as demais instâncias da realidade social na esfera política. Ao diminuir, por exemplo, o papel das classes sociais e aumentar o dos grupos de

16 Esta parece ser exatamente a imagem que Faoro (1997) tem do materialismo histórico.

17 Igual constatação pode ser atribuida a Hodgson (1993). Este afirma que, na agenda de pesquisa da NEl, a proposição principal é a questão da emergência das instituições e sua eficiência comparativa. 
status, constituídos a partir da ordem política, ele reduz o espaço para a compreensão de relaçóes tipicamente econômicas e economicamente condicionadas. Sobre isso, veja o que diz o próprio autor, para quem as "atividades econômicas, os interesses, os contratos náo se reduzem, dentro deste contexto social, ao ganho, ao lucro e às vantagens materiais. Tudo se subordina à gloria, à honra, ao incremento dos valores que o estamento corporifica" (FAORO, 1997, p. 67).

Pode-se reforçar o que foi dito tomando-se o caso da chamada Revoluçáo de 1930, ponto culminante de um longo processo de instauraçáo da ordem burguesa e do capitalismo no Brasil, mas que, na visáo de Faoro (1997), não passou de um rearranjo conservador do estamento, ao aglutinar as classes estruturando-as sob o comando autoritário. Assim, segundo o próprio autor, "destruída a confiança no aparelhamento presidencial, rompida a política dos governadores, era necessário colocar, na área vazia, um corpo de domínio estruturado por todas as classes, comandadas autoritariamente" (FAORO, 1997, p. 679). Esse corpo, ainda que gerado pelas circunstâncias, teria sido "moldado historicamente num leito permanente, embora transitoriamente obscurecido" (FAORO, 1997, p. 717).

Ademais, na explicação de Faoro (1997), categorias como moeda, mercado, burguesia, mercantilismo e capitalismo, apesar de fazerem referência ao domínio do econômico, têm motivaçáo claramente na esfera política. Dito de outro modo, o argumento de Faoro (1997) se aplica bem quando entendido sob a ótica do conceito de "fenômenos economicamente relevantes" de Weber. Isso porque, na sua explicação, toda a dinâmica histórica portuguesa, e posteriormente a brasileira, é concebida como estando sob a influência de circunstâncias não econômicas que geraram consequências econômicas. A prova maior disso é o capitalismo, que se constituiu a partir da esfera política por influência e orientação do estamento.

Esse argumento pode ser reforçado chamando-se a atenção para a forma como a economia brasileira muda no tempo, isto é, a partir dos interesses da camada dirigente, que, de posse dos instrumentos políticos derivados do aparelhamento estatal, suaviza o impacto desagregador do capitalismo, compatibilizando-o com o seu esquema de domínio. Um exemplo mais concreto também extraído da década de 1930 ajuda a esclarecer esse ponto. Para os autores ligados à Cepal, esse período representa um momento de transformaçáo econômica qualitativa. Em uma situaçáo de grave crise externa, os centros de 
decisão foram internalizados, o investimento e o mercado interno tomaram a precedência em relaçáo ao setor externo na geração da renda nacional. Esse processo é denominado de Substituiçáo de Importaçóes (PSI), e sua dinâmica gera açóes que podem ser enquadradas dentro daquilo que Weber (2001) designou tanto por "fenômenos econômicos estritos" quanto por "fenômenos econômicos condicionados". Para os primeiros, salienta-se que o próprio motor do PSI sáo os recorrentes estrangulamentos externos, demandando medidas de políticas estritamente econômicas voltadas a facilitar o desempenho da economia, como o controle de importação e a manipulação das taxas de câmbio. Para os "fenômenos econômicos condicionados", destaca-se, conforme Fonseca (2003, p. 147), a açâo estatal no sentido de promover uma série de instituiçóes, como:

a criação e/ou alteração de leis, códigos, órgãos, ministérios, regulamentação de relações de propriedade... que revelam a consciência e a intencionalidade do governo de direcionar a economia para o mercado interno, sob a liderança do setor industrial.

Preso ao seu modelo, que pressupóe "a precedência do Estado sobre a sociedade, os arranjos de elite e a dominaçáo do estamento burocrático" (FONSECA, 1989, p. 148), Raymundo Faoro não percebeu nem os "fenômenos econômicos estritos", nem os "econômicos condicionados". Como consequência, o autor acabou se limitando a classificar as várias mudanças substantivas na história da sociedade brasileira como sendo mais de forma do que de conteúdo.

Sintetizando o que foi dito, se os círculos anteriores propostos por Boettke e Storr (2002) fossem usados para descrever o conteúdo de Os donos do poder, poder-se-ia conceber que o círculo do político seria o maior, englobando, respectivamente, o do social e o do econômico.

\section{Conclusão}

Se, por um lado, as Ciências Sociais caminham no sentido de fazer convergir os resultados dos trabalhos das suas diversas áreas, principalmente por dotar a economia de mais conteúdo histórico e institucional, há, por outro, diversos questionamentos quanto à forma como isso tem sido feito. As críticas mais comuns se dirigem às tentativas da NEI e da Nova Sociologia Econômica de, respectivamente, subsocializarem e sobressocializarem o comportamento 
humano. Nesse caso, a sociologia econômica de Weber apresenta-se como algo relevante, na medida em que o seu alicerce conceitual permite a preservaçáo dos distintos níveis do embeddedness.

No Brasil, a produçáo intelectual de Weber legou um vasto arsenal na explicaçấo do descompasso político, econômico e social do país. Uma questáo que se coloca é a de entender, à luz desse interesse crescente pela sociologia econômica weberiana, a forma como um importante intérprete do Brasil faz uso das categorias do autor para explicar a realidade brasileira. No caso de Raymundo Faoro, sabe-se, ademais, que uma das suas motivaçóes foi a de fazer uso de um referencial teórico que o distanciasse do marxismo ortodoxo. No seu entender, as explicaçóes baseadas em tal concepçáo de mundo se constituíam em um dogma, primeiro por tentarem derivar leis gerais da história e, em segundo lugar, por trazerem explicitamente a determinação das instâncias do social e do político pela do econômico.

Para este trabalho, apesar dos esforços de Faoro (1997), constatou-se a natureza semelhante do seu equívoco e a do marxismo ortodoxo, que ele tanto criticou. Sua abordagem também promove uma explicaçáo monocausal da realidade e do "atraso" brasileiro, não com o predomínio do econômico, mas com o do político sobre as outras instâncias da realidade social. Isso pode ser confirmado pelo próprio autor, ao admitir a "autonomia da esfera política, que se manifesta com objetivos próprios, organizando a naçáo a partir de uma unidade centralizadora" (FAORO, 1997, p. 738).

Pode-se afirmar, em conclusáo, que a ênfase excessiva de Faoro (1997) no aspecto "político" traz uma importante contribuição ao entendimento da realidade brasileira, a do papel do Estado em sua formaçáo e seu legado. Mas náo se pode deixar de mencionar também as razóes de seu equívoco. Estas residem precisamente no fato de o autor se valer dos conceitos de Weber e náo da sua metodologia e do seu individualismo sofisticado, que preserva a intençáo e o sentido subjetivo atribuído pelos indivíduos à ação. Sem essa orientação metodológica, portanto, náo é de se admirar que Faoro (1997) náo consiga fazer como faz Weber, tratar do social, do político e do econômico com o mesmo nível de proeminência. 


\section{Referências}

BOETTKE, P.; STORR, V. H. Post-classical political economy: polity, society and economy in Weber, Mises and Hayek. The American Journal of Economics and Sociology, New York, v. 61, n. 1, p. 161-191, jan. 2002.

CAMPANTE, R. G. O patrimonialismo em Faoro e Weber e a sociologia brasileira. DADOS. Revista de Ciências Sociais, Rio de Janeiro, v. 46, n. 1, p. 153-193, 2003.

CARVALHO, J. M. A construçáo da ordem: a elite política imperial. São Paulo: Campus, 1980.

DEQUECH, D. Instituiçōes e a relaçáo entre economia e sociologia. Estudos Econômicos, Sáo Paulo, v. 41, n. 3, jul./set. 2011.

FAORO, R. Os donos do poder: formaçáo do patronato político brasileiro. 10. ed. São Paulo: Globo, 1997.

FONSECA, P. C. D. Sobre a intencionalidade da política industrializante do Brasil na década de 1930. Revista de Economia Política, Săo Paulo, v. 23, n. 1 (89), p. 133-148, jan./mar. 2003.

. Vargas: o capitalismo em construçāo-1906-1954. São Paulo: Brasiliense, 1989.

FRANCO, M. S. C. Homens livres na ordem escravocrata. 3. ed. São Paulo: Ática, 1976.

FREUND, J. Sociologia de Max Weber. 5. ed. Rio de Janeiro: Forense-Universitária, 2006.

GALVAN, C. G. Colônia, estamento, capitalismo político: um enriquecimento de idéias na leitura livre de Faoro. In: ENCONTRO NACIONAL DE ECONOMIA POLÍTICA, 6., São Paulo, 2001. Anais... Sáo Paulo: FGV, 2001.

GERTH, H.; MILLS, W. Introduçâo. In: WEBER, M. Ensaios de sociologia. 3. ed. Organizaçáo e introduçáo de H. G. Gerth e C. Wright Mills. Rio de Janeiro: J. Zahar, 1974.

HODGSON, G. M. Institutional economics: surveying the 'old' and the 'new'. Metroeconomica, v. 44, n. 1, p. 1-28, fev. 1993.

LESSA, R. O longínquo pesadelo brasileiro. In: GUIMARÁES, J. (Org.). Raymundo Faoro e o Brasil. Sáo Paulo: Fundaçáo Perseu Abramo, 2009. p. 63-76.

RINGER, F. A metodologia de Weber: unificaçáo das ciências culturais e sociais. Saáo Paulo: Edusp, 2004. (Série Ensaios de Cultura, 26).

SOUZA, J. A ética protestante e a ideologia do atraso brasileiro. In: SOUZA, J. (Org.). O malandro e o protestante. Brasília: Ed. da UnB, 1999. p. 17-54. 
SWEDBERG, R. Max Weber e a ideia de sociologia econômica. Rio de Janeiro: UFRJ; Sáo Paulo: Beca Produçôes Culturais, 2005. (Coleçáo Economia e Sociedade).

. The new 'Battle of Methods'. Challenge, v. 33, n. 1, p. 33-38, Jan./Feb. 1990.

WEBER, M. A ética protestante e o "espírito" do capitalismo. 8. ed. Săo Paulo: Pioneira: 1994.

Economia e sociedade: fundamentos da sociologia compreensiva. Brasília: Ed. da UnB, 1991.

. Metodologia das ciências sociais. Campinas: Cortez: Ed. da Unicamp, 2001. Partes 1 e 2.

Recebido em: 19/05/2013

Aprovado em: 13/05/2014

\section{Faoro, Weber and the articulation of various dimensions of social reality in brazilian explanation of-backwardness}

\section{Abstract}

Max Weber's thought, at the moment when economists and sociologists seek to converge their work, is presented as a plausible alternative to think about the interrelation between the various fields of Social Sciences. In Brazil, the ideas of Weber constituted one of the most notable influences to understand the country's problems. Following along this line, this paper aims to examine Raymundo Faoro's Os donos do poder (The owners of power). Weberian interpretation of Brazil, the articulation between the economic, social and political fields. The underlying assumption is that, viewed in the light of Weber's formulations, Faoro subsumes all different social actions in a unique dimension, namely politics, advancing a monocausal explanation of both the "backwardness" and the dynamics of Brazilian reality.

Keywords: Max Weber. Raymundo Faoro. Embeddedness. Institutions. Economic Backwardness. 